\title{
Events and Books in the Spbere of the Study of Legal and Constitutional History in Hungary in 2018
}

Keywords: scholarly events, Hungary, legal and constitutional history, academic degrees, conferences Słowa kluczowe: wydarzenia naukowe, Węgry, historia państwa i prawa, stopnie naukowe, konferencje

2018 was a productive and successful year for the study of Hungarian Legal History because among Hungarian legal historians, or foreign historians working in Hungary, there were awarded one D.Sc. degree, one habilitation, and three $\mathrm{PhD}$ degrees, along with the publication of 17 books dealing with issues in the sphere of Hungarian legal history. I focused strictly on the scholars and departments of Hungarian and European Legal History, to the exclusion of scholars and departments of Roman Law. This report also reviews scholarly works in legal history published in Hungary, as well as important legal history conferences held in Hungary.

\section{Academic degrees}

a) D.Sc. in legal history

István Sándor, an associate professor of the Department of Roman Law and Comparative Legal History at Eötvös Lóránd University in Budapest, received the postdoctoral academic degree of Doctor of the Hungarian Academy of Sciences. D.Sc. is the abbreviation of this title in Hungary. His public defense was held in the headquarters of the Hungarian Academy of Sciences on $19^{\text {th }}$ December 2018. The title of his thesis was “A vagyonvédelem jogi eszközeinek legújabb nemzetközi tendenciái” [The newest international tendencies of the property protection legal instruments]. He analysed the institution of the legal trust in numerous countries. It is a current research topic in 
Hungary $^{1}$, because the trust is a new institution in the Hungarian Civil Code of 2013. Professor Sándor is not a classic legal historian. He also researches effective civil law. But an important chapter of his thesis was the presentation of the trust's international history with special regard to practices in various states of the United States and in England. ${ }^{2}$

b) Habilitation in legal history

György Képes, the senior lecturer of the Department of the History of Hungarian State and Law at Eötvös Lóránd University Budapest, held his habilitation lectures in Debrecen on $6^{\text {th }}$ November, 2018. Based on his research into Scandinavian Constitutional History, he spoke first to the students about the royal law of 1665 as the written Constitution of the Danish Absolute Monarchy. ${ }^{3}$ The topic of the second lecture, which was presented to members of the expert public, was the formation of the head of state's authorities in the period of the Hungarian provisional arrangements. Based on the favorable votes of the jury (professors Béla Szabó, professor, Elemér Balogh, professor, István Stipta, professor, Attila Horváth, and professor Zoltán Szente) and the students, György Képes was awarded his habilitation.

c) LL.D. in legal history

1) Ádám Farkas, a senior lecturer at the National University of Public Service, Budapest, was awarded the LL.D. degree. He was an LL.D. student in the Doctoral School of Law and Political Science at Széchenyi University, Györ. His research topic was the army and military criminal law. ${ }^{4}$ The title of his thesis was "Az állam fegyveres védelmének alapvonalai és Kiegyezést követő polgári evolúciója” [The Basic of the state's armed forces and its evolution after the Austro-Hungarian Compromise]. ${ }^{5}$ His public defense was in Györ on $13^{\text {th }}$ September 2018, and his supervisors were Prof. Barna Mezey and Assoc. Prof. Attila Barna. His reviewers were Prof. Elemér Balogh, the head of Department of European Legal History at the University of Szeged, and Assoc. Prof. Zoltán Hautzinger from the National University of Public Service.

1 I. Sándor, Property and Trust Law in Hungary, Alphen aan den Rijn 2017.

2 I. Sándor, A vagyonvédelem jogi eszközeinek legújabb tendenciái [The Newest International Tendencies of Property Protection Legal Instruments], DS.c. Thesis, Budapest 2018, http://real-d.mtak.hu/1085/ [access: 23.08.2019].

3 Gy. Képes, Dánia alkotmánytörténete a 13. századtól napjainkig [The Constitutional History of Denmark from the $13^{\text {th }}$ Century to the Present], Budapest 2009; Gy. Képes, Az 1814. évi norvég alkotmány [The Norwegian Constitution of 1814], "Jogtörténeti Szemle" 2014, vol. XVI, no. 1, pp. 26-38; Gy. Képes, Svédország alkotmánya és közigazgatása Gustav Vasától XII. Károlyig (1523-1718) [The Constitution and Public Administration of Sweden from Gustav Vasa to Charles XII (1523-1718)], "Jogtörténeti Szemle" 2011, vol. XIII, no. 3, pp. 29-39.

4 Á. Farkas, R. Kelemen, A magyar katonai büntetőjog a 19. század második felétöl az 1912-es nemzeti jogalkotásig [Hungarian Military Criminal Law from the Second Half of $19^{\text {th }}$ Century to the National Legaislation of 1912], "Szakmai Szemle" 2016, vol. XIV, no. 1, 171-184.

5 Á. Farkas, Az állam fegyveres védelmének alapvonalai és Kiegyezést követö polgári evolúciója [The Groundlines of the States Armed Defence and Its Evolution after the Austro-Hungarian Compromise], $\mathrm{PhD}$ Dissertation, Budapest 2018. 
2) Máté Pétervári, the author of this report, made his public defense of his LL.D. thesis on $7^{\text {th }}$ November 2018. He was an LL.D. student at the Department of the History of Law at the University of Szeged, and his supervisor was Assoc. Prof. Norbert Varga. He researched the history of public administration in the $19^{\text {th }}$ century. ${ }^{6}$ The title of his dissertation was "A járások kialakítása Magyarországon az 1870: XLII. tc. alapján” [The Establishment of Districts on the Basis of Act 42 of 1870]. ${ }^{7}$ His reviewers were Prof. István Szabó, the head of the Department of Legal History at Pázmány Péter Catholic University, and Prof. Barna Mezey, head of the Department of the History of Hungarian State and Law at Eötvös Lóránd University in Budapest, who both recommended the conferring of the academic title on his LL.D. thesis.

3) Da Lu held his public defense of his LL.D. thesis at the University of Szeged on $12^{\text {th }}$ November 2018. He was the first Chinese LL.D. student at the University of Szeged. He began his LL.D. program in 2015 in the Department of Hungarian Legal History at the University of Szeged. His supervisor was also Assoc. Prof. Norbert Varga. Conducting his studies in English, he compared the Chinese constitution with the communist constitutions of Czechoslovakia, Hungary, and Poland. ${ }^{8}$ The title of his dissertation was Development of the Constitution Between China and the Visegrad States During the Communist Period: A Comparative Perspective. ${ }^{9}$ His reviewers were Hungarian academics, Assoc. Profs. Zsuzsanna Peres, legal historian (National University of Public Service, Budapest) and Gergely Salát, sinologist and head of the Department of Chinese Studies (Pázmány Péter Catholic University, Budapest), but the public defense jury was international because Assoc. Profs. Maciej Mikuła (Jagiellonian University in Krakow) and Tomáš Gábriš (Comenius University in Bratislava) were members of the jury.

2. Monographs and books in the sphere of Hungarian legal history

In 2018, a general work in Hungarian about the Legal History of Transylvania ${ }^{10}$ edit- $^{-}$ ed by Prof. Emőd Veress from Sapientia Hungarian University of Transylvania was pub-

6 M. Pétervári, One Empire and Two Ways of Public Administration: The Second Level Administrative Division in Austria-Hungary, "Journal on European History of Law" 2018, vol. IX, no. 2, pp. 133-139; M. Pétervári, Die Bezirkshauptmannschaft und das Stuhlrichteramt - Vergleichende Prüfung der Bezirksverwaltung in der Österreichisch-Ungarischen Monarchie [The Bezirkshauptmannschaft and the Office of the District Administrator - Comparative Examination of the District Administration in the Austro-Hungarian Compromise], “Acta Universitatis Szegediensis. Forum. Acta Juridica et Politica” 2018, vol. VIII, no. 2, pp. 311-321; M. Pétervári, The Establishment of the Districts in Hungary after the Austro-Hungarian Compromise, [in:] New Studies in History and Law, eds. N. Varga, D. A. Frenkel, Athens 2019, pp. 65-77.

M. Pétervári, A járások kialakitása Magyarországon az 1870:XLII. tc. alapján [The Establishment of Districts on the Basis of Act 42 of 1870], PhD Dissertation, Szeged 2018, http://doktori.bibl.u-szeged. hu/9934/1/disszertáció-Pétervári_Máté.pdf [access: 23.08.2019].

8 Lu Da, The Birth of Communist Party and Soviet Constitution between China and Hungary. "Journal on European History of Law" 2017, vol. VIII, no. 2, pp. 87-99; Lu Da, The Similarity of Its first Socialist Constitution between China and Hungary, [in:] Jog határok nélkül [Law without Borders], ed. Zs. Fejes, Szeged 2018, pp. 55-59.

9 Lu Da, Development of the Constitution Between China and the Visegrad States During the Communist Period: A Comparative Perspective, PhD Dissertation, Szeged 2018, http://doktori.bibl.u-szeged.hu/9932/1/ dissertation_Da_Lu.pdf [access: 23.08.2019.].

10 Erdély jogtörténete [Legal History of Transylvania], ed. E. Veress, Kolozsvár 2018. 
lished in Kolozsvár. He invited recognized researchers in the given subject to write the individual chapters. This work was the product of a cooperative effort among Hungarian and Transylvanian historians and legal historians with the support of the Hungarian Ministry of Justice. The volume remedies a great deficiency because a thorough and detailed modern presentation of Transylvanian legal history was missing in Hungarian academic literature.

Prof. Mária Homoki-Nagy, the head of the Department of Hungarian Legal History at the University of Szeged, wrote a monograph about the testaments of the villeins in Szentes between 1779 and 1849. ${ }^{11}$ Szentes was an oppidum town in southeastern Hungary during this timeframe. The author examined the testaments from the viewpoint of legal history and legal ethnography, therefore the book was published as the $5^{\text {th }}$ volume of the Legal Culture-historical and Legal Ethnographical Book Collection. This series is produced by the Tárkány Szücs Ernő Legal Culture-historical and Legal Ethnographical Research Group. Mária Homoki-Nagy analysed the appearance of the legal institutions pertinent to inheritance in the testaments, wherein she demonstrates the functioning of customary law in the life of the folk on the Great Hungarian Plain (Alföld).

Prof. Barna Mezey, the head of Department of the History of Hungarian State and Law at Eötvös Lóránd University in Budapest, published a monograph about European and Hungarian penitentiary law. ${ }^{12}$ The volume is a synthesis and a summary of several decades of the author's work. He examined mainly the influence of penitentiary laws of numerous other European countries on Hungarian regulations of the $19^{\text {th }}$ century.

Under the leadership of Ferenc Deák, the outstanding Hungarian statesman in Reform Era who was the dominant figure of the codification of the penal law and the commercial law, and later the Hungarian leader of the tying the Austro-Hungarian Compromise, the Hungarian Royal Ministry of Justice was established in accordance with Act 3 of 1848 , but the functioning of the Ministry ceased in 1849 after the defeat in the Hungarian War of Independence. It was reshuffled after the Austro-Hungarian Compromise in 1867, and the new organ was a very effective actor in Hungarian legal codification until the onset of World War II. Several great Ministers of Justice were appointed from Hungary. But a detailed examination of the history of the Ministry of Justice was missing from the writings in legal history. Tamás Antal, who is an associate professor of the Department of European Legal History at the University of Szeged produced this work on the basis of archival material with the support of the Ministry of Justice in $2018 .{ }^{13}$ His work was very difficult because the documents of the Ministry of Justice were destroyed by fire during the War of Independence in 1956. He was able to use the remaining documents during his research.

11 M. Homoki-Nagy, „Az általam megkért hiteles tanúk elött következö végső rendelésemet tészem...”” Jobbágy-parasztok végrendeletei Szentes mezövárosában [, I Make the Following Last Provisions before Certified Witnesses whom I Requested..." The Villeins-peasants'Testaments in the Oppidum Town of Szentes], Szekszárd 2018.

12 B. Mezey, A börtönügy a 17-19. században [Penology in the 17-19 th Centuries], Budapest 2018.

13 T. Antal, Az Igazságügyi Minisztérium története (1867-1944). Fejezetek a polgári kor évtizedeiböl [The History of the Ministry of Justice (1867-1944). Chapters from the Decades of Bourgeois Era], Budapest 2018.

Kronika wydarzeń naukowych - Cbronicle of scholarly events 
Gábor Rokolya is a civil law notary in Budapest, who dealt with the history of the Hungarian civil law notaryship ${ }^{14}$ on the basis of archival material. ${ }^{15}$ He published two books in 2018. The first book was a second, revised edition of his dissertation in deluxe binding. ${ }^{16}$ The other book recounted the work of István Gidófalvy, who was Royal Civil Notary in Szászrégen (Reghin), and in Kolozsvár (Cluj) from $1895^{17}$, which cities were situated in Transylvania. The Transylvanian royal civil law notary worked at the turn of the $19^{\text {th }}$ and $20^{\text {th }}$ centuries, and was the supporter and founder of numerous communal mutual loan societies. The first chapter of the book contains Rokolya's account of Gidófalvy's life. The next chapters include a selection of Gidófalvy's publications and interesting stories from the office of the royal civil notary by Rózsika Czecz, who was the cousin of Gidófalvy's wife.

In 2018, the Hungarian Society of Jurists (Magyar Jogász Egylet) published a collection of the Ministry of Justice documents about the Novel of 1977, which modified the Civil Code of 1959. The introductory study was written by Péter Nagy, who is an assistant lecturer in the Department of Legal History, Legal Theory, and Canon Law at Károli Gáspár University in Budapest. ${ }^{18}$

Finally, the Department of Roman Law and Comparative Legal History at Eötvös Lóránd University in Budapest issued the $4^{\text {th }}$ edition of a textbook about comparative legal history for law students. ${ }^{19}$

\section{Collections of essays and conferences}

Hungary commemorated the $150^{\text {th }}$ anniversary of the Austro-Hungarian Compromise in 2017, therefore Eötvös Lóránd University and the Hungarian Academy of Science organized a conference in March 2017. The volume of the conference was published with

14 The Hungarian civil law notaries appeared first in Hungary in the era of neoabsolutism (1851-1860), but this period was ruled by the unifying efforts of Habsburg in the Empire, therefore the notaryship was ceased in 1860. The Hungarian National Assembly passed Act concerning Hungarian Civil Law Notaries in 1874. Their authorities were the drafting of legal documents and testaments.

15 G. Rokolya, Lawyers, Civil Law Notaries vs. Municipal Scriveners. The Particularity of Hungarian Legal History: The Private Activities of Scriveners, "Journal on European History of Law" 2018, vol. IX, no. 2 , pp. $140-147$.

16 G. Rokolya, A közjegyzői intézmény fejlödése a polgári korban [The Development of Notarial Institution in the Bourgeois Era], Budapest 2018.

17 G. Rokolya, Dr. Gidófalvy István (1859-1921) a szövetkezet alapitó [Dr. István Gidófalvy (18591921) the Founder of Co-operative], Budapest 2018.

18 P. Nagy, A Polgári Törvénykönyvröl szóló 1959. évi IV. törvény 1977-es felülvizsgálata a levéltári források tükrében [The Review of Act 4 of 1959 Concerning the Civil Code on the Basis of Archival Sources in 1977], Az Igazságügyi Minisztérium iratanyaga az 1959-es Polgári Törvénykönyv 1977. évi novellájának elökészitésével és hatályba léptetésével kapcsolatban [The Documents of the Ministry of Justice in Connection with Novel (1977) of the Civil Code of 1959's Being Prepared and Taking Effect], Budapest 2018, pp. 9-25.

19 A. Földi, M. Kelemen, K. Károly, E. Márkus, B. Rigó, I. Siklósi, Összehasonlító jogtörténet [Comparative Legal History], Budapest 2018.

Kronika wydarzeń naukowych - Cbronicle of scholarly events 
11 studies in 2018. The book consisted of three studies about private law ${ }^{20}$, two papers analysing the Hungarian codification of penal $l^{2} w^{21}$, and works by two authors examining the Compromise and its antecedents from the viewpoint of two Hungarian statesmen, Ferenc Deák and István Széchenyi. ${ }^{22}$ Beyond this, Assoc. Prof. Gábor Béli presented the influence of the Quadripartitum, which was a modification of the Tripartitum from the $16^{\text {th }}$ century, the Dualism ${ }^{23}$, Károly Kisteleki wrote about Hungarian citizenship law ${ }^{24}$, and Prof. István Szabó illustrated the demise of the Austro-Hungarian Monarchy. ${ }^{25}$

The record of proceedings of the $7^{\text {th }}$ Conference on Legal History in Szeged was published with 16 studies in 2018. ${ }^{26}$ It is an international volume of essays, including 10 authors from Hungary, four researchers from Poland, and one each from Croatia and Belgium.

Prof. Barna Mezey, who works for Eötvös Lóránd University, was the Dean of the Law Faculty and the Rector of the university. His research topic is mainly the history of penal law. In 2018 Mezey's colleagues celebrated the $65^{\text {th }}$ anniversary of his birth by producing a volume of studies. ${ }^{27}$ The book contains 35 papers from Mezey's admirers, which were edited by assistant lecturer Gergely Gosztonyi, and Prof. T. Mihály Révész. Another volume of studies was also published by Eötvös Lóránd University which in-

20 A. Menyhárd, A jogfejlödés gazdasági alapjairól (1867-1944) [Concerning the Economic Foundations of Legal Development (1867-1944)], [in:] A kettös monarchia. Die Doppelmonarchie [The Double Monarchy. Die Doppelmonarchie], eds. G. Máthé, A. Menyhárd, B. Mezey, Budapest 2018, pp. 161-178; M. Homoki-Nagy, Magánjogi kodifikációnk kérdései [Questions Pertaining to the Codification of Private Law], [in:] A kettös monarchia. Die Doppelmonarchie [The Double Monarchie. Die Doppelmonarchie], eds. G. Máthé, A. Menyhárd, B. Mezey, Budapest 2018, 179-201; A. Horváth, A kereskedelmi törvény - 1875. évi XXXVII. tc. [The Commercial Act - Act 37 of 1875], [in:] A kettös monarchia. Die Doppelmonarchie [The Double Monarchy. Die Doppelmonarchie], eds. G. Máthé, A. Menyhárd, B. Mezey, Budapest 2018, pp. 203-246.

21 E. Balogh, A magyar büntetöjogi kodifikáció genezise [The Genesis of Hungarian Penal Law Codification], [in:] A kettös monarchia. Die Doppelmonarchie [The Double Monarchy. Die Doppelmonarchie], eds. G. Máthé, A. Menyhárd, B. Mezey, Budapest 2018, pp. 247-277; B. Mezey, A kodifikáció terhe [The Burden of Codification], [in:] A kettös monarchia. Die Doppelmonarchie [The Double Monarchy. Die Doppelmonarchie], eds. G. Máthé, A. Menyhárd, B. Mezey, Budapest 2018, pp. 279-302.

22 G. Máthé, Deák Ferenc közjogi dogmatikai remeke [The Public Law Dogmatic Masterpiece of Ferenc Deák), A kettős monarchia. Die Doppelmonarchie (The Double Monarchy. Die Doppelmonarchie]), eds. G. Máthé, A. Menyhárd, B. Mezey, Budapest 2018, pp. 39-63; L. Rácz, Aki nem érhette meg a kiegyezést [Who Can Not Live to See the Compromise], [in:] A kettös monarchia. Die Doppelmonarchie [The Double Monarchy. Die Doppelmonarchie], eds. G. Máthé, A. Menyhárd, B. Mezey, Budapest 2018, pp. 115-160.

23 G. Béli, A Quadripartitum közjogi megoldásai [The Public Law Solutions of Quadripartitum], [in:] A kettös monarchia. Die Doppelmonarchie [The Double Monarchy. Die Doppelmonarchie], [in:] eds. G. Máthé, A. Menyhárd, B. Mezey, Budapest 2018, pp. 11-38.

24 K. Kisteleki, Magyar nemzet - magyar állampolgárság [Hungarian Nation - Hungarian Citizenship], [in:] A kettös monarchia. Die Doppelmonarchie [The Double Monarchy. Die Doppelmonarchie], eds. G. Máthé, A. Menyhárd, B. Mezey, Budapest 2018, pp. 79-114.

25 I. Szabó, Az Osztrák-Magyar Monarchia megszünésének közjogi hatásai [The Public Law Effects of the Demise of the Austro-Hungarian Monarchy], [in:] A kettös monarchia. Die Doppelmonarchie [The Double Monarchy. Die Doppelmonarchie], eds. G. Máthé, A. Menyhárd, B. Mezey, Budapest 2018, pp. 303-325.

26 Codification Achievements and Failures in the $19^{\text {th }}-20^{\text {th }}$ Century, eds. M. Homoki-Nagy, N. Varga, Szeged 2018.

27 Jogtörténeti Parerga II. Ünnepi tanulmányok Mezey Barna 65. születésnapja tiszteletére [Legal Historical Parerga II. Festive Studies in Honour of $65^{\text {th }}$ Anniversary of the Birth of Barna Mezey]), eds. G. Gosztonyi, T. Révész, Budapest 2018.

Kronika wydarzeń naukowych - Cbronicle of scbolarly events 
cludes legal-historical papers produced by its own students, as well as by some from the University of Zagreb. ${ }^{28}$ This book is a result of the second Croatian-Hungarian Legal History Summer School in Zagreb in 2017.

Research into judicial history was very active in 2017, but the topic was less popular in 2018, although members of the Department of Legal History in Debrecen elaborated the history of one town's jurisdiction in this year too. The judicial history of Hajdúböszörmény was examined by the cooperation of archivists, legal historians, and the custodian of the Hajdúsági Museum in Hajdúböszörmény. Two legal historians from Debrecen participated in the work: Judit Balogh ${ }^{29}$ and Zoltán Megyeri-Pálffi ${ }^{30}$, who was also the editor of the book.

A ten-member research group, which examined the history of professions in public administration and jurisdiction, carried on its work in cooperation with the National University of Public Service, and the Department of Hungarian Legal History of the University of Szeged. The researchers published the new studies in the journal of the Faculty of Law of the University of Szeged. ${ }^{31}$

28 Sic itur ad astra II: Collection of Student Papers on Hungarian and Croatian Legal History 2017, eds. G. Gergely, M. Krešić, K. Bódiné Beliznai, Zagreb 2018.

29 J. Balogh, A hajdúkerületi törvényszék büntetőbíráskodása a 18-19. században. Nagy Sándor bíróság és itélkezéstörténeti munkássága [The Practice of Court of Justice of Heyduck Circle in Penal Law in $18^{\text {th }}$ $19^{\text {th }}$ centuries. Work of Sándor Nagy about the Courts and Judicature of Heyducken]), [in:] A jogszolgáltatás története Hajdúböszörményben [History of Justice in Hajdúböszörmény], eds. Z. Megyeri-Pálffi, Debrecen 2018, pp. 47-57.

30 Z. Megyeri-Pálffi, A Hajdúböszörményi Járásbiróság megszervezésének és elhelyezésének története [History of the Organising and the Placement of Hajdúböszörmény District Court], [in:] A jogszolgáltatás története Hajdúböszörményben [History of Justice in Hajdúböszörmény], ed. Z. Megyeri-Pálffi, Debrecen 2018, pp. 59-77.

31 J.T. Nagy, A jogászság szerepe a jogi népéletkutatásban (1939-1948) [The Role of Lawyers in Legal Ethnography (1939-1948)], "Acta Universitatis Szegediensis. Forum. Acta Juridica et Politica” 2018 , vol. VIII, no. 1, pp. 177-201; L. Papp, Iparjogvédelmi bíráskodás Magyarországon [The Jurisdiction of Protection of Industrial Property in Hungary], "Acta Universitatis Szegediensis. Forum. Acta Juridica et Politica" 2018, vol. VIII, no. 1, pp. 227-239; M. Pétervári, Az igazságszolgáltatás és a közigazgatás elválasztása járási szinten [The Separation of Jurisdiction and Administration on the Level of Districts], "Acta Universitatis Szegediensis. Forum. Acta Juridica et Politica” 2018, vol. VIII, no. 1, pp. 241-253; G. Rokolya, A közjegyzöi intézmény átalakulása a rendszerváltáskor (1987-1991) [The Transformation of the Civil Law Notary Institution in the Democratic Transformation (1987-1991)], “Acta Universitatis Szegediensis. Forum. Acta Juridica et Politica” 2018, vol. VIII, no. 1, pp. 283-303; T. Almási, Megjegyzések Nagymartoni Pál királyi országbiró pályájához és müködéséhez (1328-1349) [Notes to the Working Life and Activities of Pál Nagymartoni, Royal Lord Chief Justice (1328-1349)], “Acta Universitatis Szegediensis. Forum. Acta Juridica et Politica” 2018, vol. VIII, no. 2, pp. 5-34; L. Nánási, A népköztársaság ügyészségétől a köztársaság ügyészségéig [The Prosecution Service from the People's Republic to the Republic], "Acta Universitatis Szegediensis. Forum. Acta Juridica et Politica" 2017, vol. VIII, no. 2, pp. 241-279; L. Papp, Uzsorabíróság [The Usury Court], "Acta Universitatis Szegediensis. Forum. Acta Juridica et Politica” 2018, vol. VIII, no. 2, pp. 297-309; M. Pétervári, Die Bezirkshauptmannschaft und das Stuhlrichteramt - Vergleichende Prüfung der Bezirksverwaltung in der Österreichisch-Ungarischen Monarchie, "Acta Universitatis Szegediensis. Forum. Acta Juridica et Politica” 2018, vol. VIII, no. 2, pp. 311-321; G. Rokolya, Az állami közjegyzői intézmény kiépitése és müködése (1950-1956) [The Building and Function of the State Notary's Institution (1950-1956)], "Acta Universitatis Szegediensis. Forum. Acta Juridica et Politica” 2018, vol. VIII, no. 2, pp. 269-384; N. Varga, A városi tanács müködése a magyar közigazgatási rendszerben [The Operation of the City Council in the System of the Hungarian Administration]), “Acta Universitatis Szegediensis. Forum. Acta Juridica et Politica” 2018, vol. VIII, no. 2, pp. 443-471.

Kronika wydarzeń naukowych - Chronicle of scholarly events 
The collection of essays entitled “A jogtörténet új forrásai: Jogi Kultúrtörténeti és Jogi Néprajzi Digitális Adattár" [New sources of legal history research: Digital Database of Folk Law (DDFL)] was published as the $8^{\text {th }}$ volume of the Legal Culture-historical and Legal Ethnographical Book Collection. It was the final volume of the Tárkány Szúcs Ernő Legal Culture-historical and Legal Ethnographical Research Group, which was formed in 2011, and it coordinated the works of 29 researchers. The volume contains three studies by legal historians. ${ }^{32}$

Act 17 of 1867 endowed the Jewish citizens Hungary with equal rights. On the occasion of the $150^{\text {th }}$ anniversary of this act, an academic conference was organized by the University of Szeged, the Jewish Religious Community of Szeged, and the Jewish Cultural Association of Hungary on 27 November 2017. In 2018, the volume of essays of this conference was published with eight studies. ${ }^{33}$

32 M. Homoki-Nagy, A mindennapok joga a jobbágy-parasztság végrendeleteiben [The Customary Law in the Villeins-peasants' Testaments], [in:] A jogtörténet új forrásai: Jogi Kultúrtörténeti és Jogi Néprajzi Digitális Adattár [New Sources of Legal History Research: Digital Database of Folk Law (DDFL)], ed. J.T. Nagy, Szekszárd 2018, pp. 153-203; I. Kajtár, Áttekintő értékelés a jogi kultúrtörténet forrásairól, módszertani és elméleti kérdéseiről, eredményeiről [An Overview of Sources, Methodological and Theoretical Questions, and Results of Legal Cultural History], [in:] A jogtörténet új forrásai: Jogi Kultúrtörténeti és Jogi Néprajzi Digitális Adattár [New Sources of Legal History Research: Digital Database of Folk Law (DDFL)], ed. J.T. Nagy, Szekszárd 2018, p. 205-249; J.T. Nagy, A jogi népéletkutatás (1939-1948) nemzetközi elözményei, elméleti és módszertani kérdései, eredményei a hazai interdiszciplináris tudományfejlödésben [The International Antecedents, Theoretical and Methodological Issues of Hungarian Legal Ethnography (1939-1948) and their Results in the Development of Domestic Interdisciplinary Science], [in:] A jogtörténet új forrásai: Jogi Kultúrtörténeti és Jogi Néprajzi Digitális Adattár" [New Sources of Legal History Research: Digital Database of Folk Law (DDFL)], ed. J.T. Nagy, Szekszárd 2018, pp. 251-316.

33 E. Balogh, A nemzetiségi viszonyok jogi rendezése hazánkban 1848-49-ben. Jogalkotói törekvések a zsidóság emancipációjára [The Legal Settlement of the Relationships among Nationalities in Hungary in 1848-1849. Legislative Efforts for the Emancipation of Jews], [in:] Emancipáció. Integráció vagy asszimiláció. Tanulmányok az emancipációs törvény 150. évfordulója alkalmából [Emancipation. Integration or Assimilation. Studies on the Occasion of $150^{\text {th }}$ Anniversary of the Emancipation Act], ed. J. Molnár, PécsSzeged 2018, pp. 11-29; M. Homoki-Nagy, “Az emancipációtól a recepcióig”. A zsidók politikai és jogi egyenjogúsítása az egyházpolitikai küzdelmek között [,From Emancipation to Reception” Political and Legal Emancipation of Jews in the Midst of Ecclesiastical-Political Struggles], [in:] Emancipáció. Integráció vagy asszimiláció. Tanulmányok az emancipációs törvény 150. évfordulója alkalmából [Emancipation. Integration or Assimilation. Studies on the Occasion of $150^{\text {th }}$ Anniversary of the Emancipation Act], ed. J. Molnár, PécsSzeged 2018, pp. 31-54; Á. Harkai, A recepciós törvény országgyülési tárgyalása az Egyenlöség cikkeinek tükrében, 1893-1895 [The Parliamentary Debate of the Reception Act as Reflected in the Articles of the Weekly Egyenlöség, 1893-1895], [in:] Emancipáció. Integráció vagy asszimiláció. Tanulmányok az emancipációs törvény 150. évfordulója alkalmából [Emancipation. Integration or Assimilation. Studies on the Occasion of 150 th Anniversary of the Emancipation Act], ed. J. Molnár, Pécs-Szeged 2018, pp. 55-80; L. Marjanucz, Asszimiláció és keresztény-zsidó vegyesházasság. Adalékok a századforduló szegedi zsidóságának társadalmi helyzetéhez [Assimilation and Jewish-Christian Intermarriages. Some Remarks on the social Position of the Jews in Szeged at the End of Century], [in:] Emancipáció. Integráció vagy asszimiláció. Tanulmányok az emancipációs törvény 150. évfordulója alkalmából [Emancipation. Integration or Assimilation. Studies on the Occasion of $150^{\text {th }}$ Anniversary of the Emancipation Act], ed. J. Molnár, Pécs-Szeged 2018, pp. 81-100; L. Harsányi, Az emancipáció hullámain. Zsidó egyesületek a 19. század utolsó harmadában [On the Waves of Emancipation. Jewish Associations in the Last Third of the 19th Century], [in:] Emancipáció. Integráció vagy asszimiláció. Tanulmányok az emancipációs törvény 150. évfordulója alkalmából [Emancipation. Integration or Assimilation. Studies on the Occasion of $150^{\text {th }}$ Anniversary of the Emancipation Act], ed. J. Molnár, Pécs-Szeged 2018, pp. 101-123; N. Glässer, Az emancipáció Mózese és Jozsuája. Az uralkodóház emancipáló szerepének neológ izraelita percepciói [Moses and Joshua of the Hungarian Jewish Emancipation. The Hungarian Israelite Perceptions of the Habsburg Dynasty's Role in the Emancipation],

Kronika wydarzeń naukowych - Chronicle of scholarly events 
The next book marked the achievement of a unique initiative, since it is the final volume of a two-year cooperative venture between the University of Pécs and the University of Graz. ${ }^{34}$ The objective of this collaboration was the teaching of the history of family law to the students along with their participation in research work on the topic. The supervising teachers gave a catalogue of questions to the Austrian and Hungarian students who were then able to work up these questions on the basis of Austrian and Hungarian legal regulation with the support of the Austrian (Markus Steppan, Susanne Kissich) and Hungarian academics (Eszter Cs. Herger, Balázs Somfai), as well as that of practicing lawyers. This book includes the studies produced by the 11 students along with an introduction in German from the supervising academics. ${ }^{35}$

The Pázmány Péter University organized an international conference entitled "Verwaltungs- und Verfassungsgerichtsbarkeit" on 17 December 2018. This conference about the public administration courts and constitutional court was conducted in German. The participants were Austrian and Hungarian researchers, and four among them dealt with legal history: Prof. Wilhelm Brauneder (University of Vienna and Andrássy University Budapest), Prof. Gábor Máthé (National University of Public Service), Prof. Barna Mezey (Eötvös Lóránd University), and Prof. István Szabó (Pázmány Péter Catholic University). Most of Hungary's legal historians participated in the International Legal History Conference of Szeged entitled "Centenaria - 1918”, which was organized on 5-7 December 2018. A principal topic of the conference was the conclusion of World War I, while the plenary session addressed the Codex Iuris Canonici of 1917. 10 PhD students and one undergraduate student held lectures in the topic of legal history in the $\mathrm{PhD}$ Students Section, and the Hungarian $\mathrm{PhD}$ students had opportunities to present the findings of their research on the first day of the conference. The lecturers in this session were legal historians (Prof. László Blazovich, Prof. Elemér Balogh, Prof. Mária Homoki-

[in:] Emancipáció. Integráció vagy asszimiláció. Tanulmányok az emancipációs törvény 150. évfordulója alkalmából [Emancipation. Integration or Assimilation. Studies on the Occasion of $150^{\text {th }}$ Anniversary of the Emancipation Act], ed. J. Molnár, Pécs-Szeged 2018, pp. 125-152; J. Molnár, "Kesztyüs liberalizmus" helyett keresztény-nemzeti fajvédelem (1919-1944) [Christian-National Race Protection for "Kid-Glove Liberalism" (1919-1944)], [in:] Emancipáció. Integráció vagy asszimiláció. Tanulmányok az emancipációs törvény 150. évfordulója alkalmából [Emancipation. Integration or Assimilation. Studies on the Occasion of $150^{\text {th }}$ Anniversary of the Emancipation Act], ed. J. Molnár, Pécs-Szeged 2018, pp. 153-186; L. Trócsányi, Zsidó tudósok hozzájárulása a magyar jogtudomány fejlödéséhez [The Contribution of Jewish Jurists to the Development of Hungarian Jurisprudence], [in.] Emancipáció. Integráció vagy asszimiláció. Tanulmányok az emancipációs törvény 150. évfordulója alkalmából [Emancipation. Integration or Assimilation. Studies on the Occasion of 150 th Anniversary of the Emancipation Act], ed. J. Molnár, Pécs-Szeged 2018, pp. 187-200.

${ }_{34}$ Gemeinsame Wurzeln und Elemente des österreichischen und ungarischen Familienrechts, eds. E.Cs. Herger, S. Kissich, M. Steppan, Leykam 2018.

35 E.Cs. Herger, Die Quellen des ungarischen Eherechts und die Wirkung des ABGB-Eherechts auf die ungarische Rechtsentwicklung, Gemeinsame Wurzeln und Elemente des österreichischen und ungarischen Familienrechts, eds. E.Cs. Herger, S. Kissich, M. Steppan, Leykam 2018, pp. 19-32; S. Kissich, Gleich- und verschiedengeschlechtliche Lebensgemeinschaften im österreichischen Recht: Charakteristika und rechtliche Anerkennung, Gemeinsame Wurzeln und Elemente des österreichischen und ungarischen Familienrechts, eds. E.Cs. Herger, S. Kissich, M. Steppan, Leykam 2018, pp. 33-50; B. Somfai, Mediation, ein wenig anders, Gemeinsame Wurzeln und Elemente des österreichischen und ungarischen Familienrechts, eds. E.Cs. Herger, S. Kissich, M. Steppan, Leykam 2018, pp. 51-58; M. Steppan, Spannungsfeld Kirche-Staat im Eherecht des aufgeklärten Absolutismus, Gemeinsame Wurzeln und Elemente des österreichischen und ungarischen Familienrechts , eds. E.Cs. Herger, S. Kissich, M. Steppan, Leykam 2018, pp. 59-77.

Kronika wydarzeń naukowych - Cbronicle of scholarly events 
Nagy, and Assoc. Prof. Levente Völgyesi) and canon lawyers. The lecturers from abroad arrived from Germany (Profs. Heinz Holzhauer and Bernd Kannowski), Poland (PhD Students Jakub Pokoj and Krzysztof Bokwa), Turkey (Prof. Fethi Gedikli and Asst. Prof. Abdullah Islamoglu), and Slovakia (Prof. Tomas Gabris, Assoc. Prof. Miroslav Lysy, and Asst. Prof. Ján Sombati). Moreover, 18 Hungarian researchers presented lectures on Thursday and Friday. Consequently, the conference in Szeged was again very popular.

Finally, I would like to mention a conference prize. Mátyás Szabó, a PhD Student of the Institute of Hungarian Constitutional and Legal History at the National University of Public Service, was awarded first prize by the jury in the Historical Section of the $21^{\text {st }}$ Spring Wind Conference of DOSZ (Association of Hungarian PhD and DLA Students). In his presentation he analysed the organization, activities, and regulations of the state security services of the 1980s. 